\title{
Effect of postcalving serum nonesterified fatty acids concentration on the functionality of bovine immune cells
}

\author{
C. Ster, ${ }^{\star}$ M.-C. Loiselle, $\dagger$ and P. Lacasse ${ }^{\star 1}$ \\ *Dairy and Swine Research and Development Centre, Agriculture and Agri-Food Canada, 2000 College, Sherbrooke, QC, Canada J1M 0C8 \\ †Department of Biology, Faculty of Sciences, Université de Sherbrooke, Sherbrooke, QC, Canada, J1K 2R1
}

\begin{abstract}
The periparturient period is marked by metabolic, hormonal, and immunological changes, which have an effect on the incidence of infectious and metabolic diseases. In a previous study, a slower increase in milk production was induced by milking cows once daily during the first week of lactation, leading to an improvement in levels of several metabolites, including nonesterified fatty acids (NEFA) and $\beta$-hydroxybutyrate (BHBA). The aim was to determine the influence of serum collected on d 2, 5, and 61 postpartum from cows milked once or twice daily on immune cell functions and to determine which of the constituents were responsible for these effects. Peripheral blood mononuclear cells (PBMC) and polymorphonuclear leukocytes were collected from healthy midlactation cows and their immune functions (i.e., proliferation and interferon- $\gamma$ production and chemotaxis, phagocytosis, and oxidative burst, respectively), were evaluated in presence of serum, NEFA, and BHBA. Proliferation of PBMC was greater with d-61 $(65.1 \pm 1.6 \%)$ serum than with $\mathrm{d}-2$ $(37.3 \pm 2.4 \%)$ or $\mathrm{d}-5(48.4 \pm 1.6 \%)$ serum and greater with d-2 and -5 serum from cows milked once (42.2 \pm 3.7 and $54.0 \pm 2.5)$ compared with cows milked twice daily $(32.4 \pm 3.0$ and $42.9 \pm 2.1)$. Proliferation was inversely correlated with the concentration of NEFA and BHBA in the serum $(\mathrm{r}=-0.86)$. Adding NEFA to d-61 serum to reach the level present in d-5 serum decreased proliferation to the level observed with d-5 serum. No effect of BHBA addition was observed. The release of interferon- $\gamma$ by PBMC was lower in d-5 serum (766 \pm $63 \mathrm{pg} / \mathrm{mL})$ than in d-61 serum $(1,187 \pm 90 \mathrm{pg} / \mathrm{mL})$ and by NEFA. Milking frequency did not affect chemotaxis, phagocytosis, or oxidative burst of polymorphonuclear leukocytes. Phagocytosis decreased over time in serum from d 2 to 61 . Similarly, oxidative burst was greater with d-5 serum $\left(12.7 \times 10^{8} \pm 1.6 \times 10^{8}\right.$ relative light units $)$ than with d-61 serum $\left(9.0 \times 10^{8} \pm 1.6 \times 10^{8}\right.$ relative light units). The NEFA had a negative effect
\end{abstract}

Received July 6, 2011.

Accepted October 5, 2011.

${ }^{1}$ Corresponding author: Pierre.lacasse@agr.gc.ca on oxidative burst, but BHBA did not. In conclusion, several immune cell functions appear affected by the NEFA concentration. Therefore, strategies that prevent increases in blood NEFA during the transition period may limit postpartum immunosuppression.

Key words: postcalving period, immune cell, nonesterified fatty acids, dairy cow

\section{INTRODUCTION}

The transition period, defined as 3 wk prepartum to $3 \mathrm{wk}$ postpartum, is a challenging time for the modern dairy cow. This period is marked by nutritional, metabolic, and hormonal changes that affect the incidence of infections and metabolic diseases (Goff and Horst, 1997). The periparturient dairy cow has nutritional requirements that exceed its dietary intake potential. This results in a temporary state of negative energy balance, during which blood glucose decreases and body tissue reserves are mobilized to provide additional energy, leading to elevated blood NEFA and BHBA (Busato et al., 2002; Goff et al., 2002; Accorsi et al., 2005). Cows with metabolic disturbances or health problems in early lactation produce less milk than healthy cows and are more likely culled, resulting in economic losses for dairy farmers (Drackley, 1999).

During the periparturient period, the dairy cow experiences a natural state of immunosuppression, which is associated with a high susceptibility to infectious diseases such as mastitis (Mallard et al., 1998; Kehrli and Harp, 2001). Parturition in dairy cattle is associated with impairment of PMNL phagocytosis and oxidative burst activity (Kehrli et al., 1989; Moreira da Silva et al., 1998; Hoeben et al., 2000) and with a decrease in the ability to fight bacterial infections. This period is marked by decreased responsiveness of blood lymphocytes to stimulation with mitogenic agents and by decreased immunoglobulin production by $\mathrm{B}$ cells (Nonnecke et al., 2003; Lacetera et al., 2005). Various hypotheses have been put forward that attribute the impairment of immune functions around the time of calving to endocrine or metabolic changes. High peripartum blood NEFA concentration was associated with impaired blood PMNL functions (Hammon et al., 
2006). In vitro, the presence of high concentrations of NEFA and BHBA can adversely affect oxidative burst and the phagocytic capacity of PMNL (Suriyasathaporn et al., 2000; Scalia et al., 2006), which suggests that these blood metabolites cause immunosuppression. Accordingly, studies have identified blood concentration of metabolites, notably NEFA and BHBA, as risk factors for mastitis (Moyes et al., 2009b) and uterine diseases (Hammon et al., 2006; Ospina et al., 2010).

Limiting milk production at the beginning of lactation to decrease the negative energy balance could affect immune function and blood metabolite concentrations. In an earlier study, a group of cows was milked once daily in their first week of lactation, and then twice daily, whereas a second group of cows was milked twice daily throughout lactation (Loiselle et al., 2009). A slow transition between dry-off and lactation led to low blood concentrations of NEFA and BHBA in cows milked once daily during the first week of lactation. Nevertheless, when cells were cultivated in conventional media, no differences were observed in vitro in the immune cell functions of the 2 groups. These results suggested that immunosuppression was not related to autonomous immune cell defects. The aim of this study was to assess whether blood composition at the beginning of lactation can impair the function of immune cells. To this end, serum samples collected from cows in the previous study were used to evaluate the influence of some of the components (especially NEFA and BHBA), abundant in early lactation sera, on the immune functions of healthy cells.

\section{MATERIALS AND METHODS}

\section{Reagents and Serum Samples}

Serum samples were taken from cows that were milked either once $(\mathbf{1} \times)$ or twice $(\mathbf{2} \times)$ daily during the first week of lactation and then twice daily for the rest of the lactation (Loiselle et al., 2009). Two hundred milliliters of blood was collected from 12 cows (5 samples from the $1 \times$ group and 7 from the $2 \times$ group) by jugular venipuncture on $\mathrm{d} 2,5$, and 61 using Vacutainer tubes (Becton, Dickinson and Co., Rutherford, NJ). The blood was centrifuged $(15 \mathrm{~min}, 3,000 \times \mathrm{g})$ and serum was stored at $-20^{\circ} \mathrm{C}$ until use. The composition of the serum was determined previously (Loiselle et al., 2009). Table 1 shows the metabolite and hormone concentrations of the different serum samples used in this study by group.

The NEFA mixture used for in vitro tests contained $45 \%$ oleic acid, $30 \%$ palmitic acid, $15 \%$ stearic acid, $5 \%$ palmitoleic acid, and $5 \%$ linoleic acid. These proportions reflect those encountered in bovine serum (Lacetera et al., 2004). All fatty acids were purchased from SigmaAldrich Canada Ltd. (Oakville, ON, Canada) and solubilized in $100 \%$ ethanol. $\beta$-Hydroxybutyrate (sodium salt) was purchased from Sigma-Aldrich and solubilized in Hank's Balanced Salt Solution (HBSS, without $\mathrm{Ca}^{2+}$ and $\mathrm{Mg}^{2+}$; Gibco Laboratories, Grand Island, NY). Sodium chloride solubilized in HBSS was used as a negative control.

\section{Animals and Experimental Procedures}

The experiment was conducted in accordance with the guidelines of the Canadian Council on Animal Care. Multiparous Holstein cows in mid to late lactation were housed at the Dairy and Swine Research and Development Centre of Agriculture and Agri-Food Canada (Sherbrooke, Quebec, Canada). Blood samples were collected by jugular venipuncture into Vacutainer tubes (Becton, Dickinson and Co.) containing EDTA and used for PMNL and peripheral blood mononuclear

Table 1. Mean $( \pm \mathrm{SD})$ metabolite and hormone concentrations in the serum samples used in vitro ${ }^{1}$

\begin{tabular}{|c|c|c|c|c|c|c|}
\hline Item & \multicolumn{3}{|c|}{$1 \times$ cows } & \multicolumn{3}{|c|}{$2 \times$ cows } \\
\hline \multicolumn{7}{|l|}{ Metabolite } \\
\hline Calcium (mg/dL) & 9.14 & $10.45 \pm 0.78$ & $10.56 \pm 0.15$ & $10.20 \pm 0.91$ & $10.13 \pm 0.94$ & $10.40 \pm 0.96$ \\
\hline Phosphorus (mmol) & 1.03 & $2.23 \pm 0.47^{*}$ & $1.64 \pm 0.49$ & $1.65 \pm 0.59$ & $1.69 \pm 0.40$ & $1.60 \pm 0.33$ \\
\hline Bilirubin $(\mu M)$ & 11.70 & $9.28 \pm 4.53$ & $6.96 \pm 2.32$ & $12.27 \pm 2.85$ & $10.53 \pm 2.91$ & $7.51 \pm 2.92$ \\
\hline \multicolumn{7}{|l|}{ Hormone } \\
\hline 17ß-estradiol (pg/mL) & 22.03 & $2.96 \pm 1.71$ & $1.56 \pm 1.10$ & $17.71 \pm 15.03$ & $2.17 \pm 0.75$ & $2.27 \pm 1.78$ \\
\hline Leptin $(\mathrm{ng} / \mathrm{mL})$ & 2.62 & $2.68 \pm 0.26$ & $2.16 \pm 0.60$ & $2.40 \pm 0.03$ & $2.35 \pm 0.35$ & $2.28 \pm 0.45$ \\
\hline Stanniocalcin-1 ( $\mathrm{ng} / \mathrm{mL})$ & 3.27 & $4.66 \pm 1.40$ & $4.06 \pm 1.48$ & $3.70 \pm 1.41$ & $3.21 \pm 1.15$ & $2.73 \pm 1.52$ \\
\hline
\end{tabular}

${ }^{1}$ Cows were milked once daily $(1 \times$ cows; $\mathrm{n}=5)$ or twice daily $(2 \times$ cows; $\mathrm{n}=7)$ during their first week of lactation. Blood samples were harvested on $\mathrm{d} 2,5$, and 61 postcalving.

${ }^{2}$ Only 1 serum sample on d 2 was available for this group.

*Indicates when $P<0.05$ between the 2 groups for the same day of sampling. 
cells (PBMC) isolation. Overall, 22 cows were used as immune cell donors.

Peripheral blood mononuclear cells were isolated as described previously by Loiselle et al. (2009). The PBMC concentration was adjusted to $2 \times 10^{7}$ cells $/ \mathrm{mL}$ in $37^{\circ} \mathrm{C}$ preheated HBSS with $0.2 \mathrm{mM}$ fluorophore carboxyfluorescein diacetate succinimidyl ester (Molecular Probes Inc., Eugene, OR) and then incubated at $37^{\circ} \mathrm{C}$ in a water-saturated $5 \% \mathrm{CO}_{2}$ atmosphere for $15 \mathrm{~min}$. Afterward, the cells were centrifuged at $300 \times g$ for 5 min, resuspended in $11 \mathrm{~mL}$ of cold Roswell Park Memorial Institute medium (RPMI; Gibco Laboratories), containing 5\% FBS (Invitrogen Corp., Carlsbad, CA) and $1 \times$ antibiotic-antimycotic (A5955, Sigma-Aldrich Corp., St. Louis, MO). The cells were incubated at room temperature for $15 \mathrm{~min}$ in the dark. The PBMC were centrifuged at $300 \times g$ for $5 \mathrm{~min}$ at $25^{\circ} \mathrm{C}$ and resuspended in RPMI medium.

The PMNL were isolated by gradient centrifugation in Ficoll-Paque Plus $(30 \mathrm{~min}$ at $540 \times g$; Amersham Corp., Arlington Heights, IL) from peripheral blood diluted with an equal volume of preheated HBSS. The packed red blood cells were lysed with Tris- $\mathrm{NH}_{4} \mathrm{Cl}$ twice and centrifuged at $210 \times g$ for $5 \mathrm{~min}$. The supernatant was discarded and the PMNL were washed with 45 $\mathrm{mL}$ of HBSS and centrifuged at $300 \times g$ for 5 min at $25^{\circ} \mathrm{C}$. The PMNL were resuspended in $5 \mathrm{~mL}$ of RPMI medium supplemented with antibiotic-antimycotic and preheated to $37^{\circ} \mathrm{C}$. The viable cells were counted with a Bright-Line Hemacytometer (Hausser Scientific, Horsham, PA) using trypan blue exclusion methodology. To remove the effect of between-cow variations in PMNL, a pooled sample of PMNL was prepared by mixing equal amounts of PMNL from 3 donors.

\section{PBMC Proliferation Assay}

The cells were distributed into the wells of a 6 -well plate $\left(3.5 \mathrm{~mL}\right.$ and $5 \times 10^{6}$ cells per well). Peripheral blood mononuclear cells (2 wells) were incubated with the mitogen concanavalin A (ConA, Sigma-Aldrich Corp.) at a final concentration of $1 \mu \mathrm{g} / \mathrm{mL}$ at $37^{\circ} \mathrm{C}$ in a water-saturated $5 \% \mathrm{CO}_{2}$ atmosphere for $3.5 \mathrm{~d}$. Peripheral blood mononuclear cells incubated without ConA served as a negative control. The experiment was performed in duplicate. The cells were subsequently centrifuged at $300 \times g$ for $5 \mathrm{~min}$ and resuspended in PBS containing $0.5 \%$ formaldehyde. The proliferation of PBMC was analyzed by flow cytometry [excitation/ emission (Ex:Em) wavelengths: $492: 517 \mathrm{~nm}$ ] on a Coulter Epics XL-MCL flow cytometer (Beckman Coulter Inc., Fullerton, CA).

To measure the effect of the different serum samples collected on different days postcalving in the 2 groups of cows, PBMC were resuspended in RPMI medium containing $1 \times$ antibiotic-antimycotic and $5 \%$ of the serum to be tested (d 2, 5, and 61 for the 2 groups of cows). This assay was performed three times in duplicate for each serum and 3 different PBMC donors.

To evaluate the effect of the postcalving concentration of NEFA and BHBA, the proliferation medium contained RPMI medium with $1 \times$ antibiotic-antimycotic and $5 \%$ of the serum samples collected on d 5 or 61 or $5 \%$ of the d-61 serum supplemented with NEFA or BHBA, or both, to reach the same concentrations as in the corresponding d-5 serum. A dose effect assay was performed using physiological concentration of these metabolites. The PBMC were resuspended in RPMI medium with $1 \times$ antibiotic-antimycotic, $5 \%$ of the pooled serum from healthy cows, and increasing doses of NEFA or BHBA, or their respective negative controls (ethanol and $\mathrm{NaCl}$, respectively).

To remove the effect of cow-to-cow variability, in the 2 previously described experiments blood was sampled from 3 cows and, after separate PBMC isolation and counting, a pooled sample containing an equal amount of PBMC from the 3 cows was prepared for use in the rest of the experiment. Experiments were performed in duplicate and repeated twice.

\section{PBMC Production of IFN-y}

For the determination of IFN- $\gamma$ concentration, 1 $\mathrm{mL}$ of the supernatant from ConA-stimulated PBMC was recovered after $24 \mathrm{~h}$ of incubation. Supernatant cytokine content was determined with a commercial kit (Endogen; Thermo Fisher Scientific Inc., Rockford, IL) as described previously (Loiselle et al., 2009).

\section{Phagocytosis Assay}

Before the phagocytosis assay, the PMNL concentration was adjusted to $5 \times 10^{6}$ cell $/ \mathrm{mL}$ in RPMI medium, $1 \times$ antibiotic-antimycotic, and $5 \%$ of the serum to be tested, and incubated for $2 \mathrm{~h}$ at $37^{\circ} \mathrm{C}$ in a water-saturated $5 \% \mathrm{CO}_{2}$ atmosphere with gentle agitation (100 rpm). The PMNL counts were verified at the beginning and end of the incubation.

After incubation, PMNL were centrifuged at 1,700 $\times g$ for $5 \mathrm{~min}$ and resuspended at a concentration of $1 \times 10^{7}$ cells $/ \mathrm{mL}$ in Krebs-Ringer PBS. The PMNL were distributed in 3 tubes, each containing $1 \times 10^{6}$ cells. Prior to their use, Fluoresbrite YO Carboxylate Microspheres $(6.0 \mu \mathrm{m}$; Polysciences Inc., Warrington, PA) were opsonized with naive cow serum diluted 1:5 in Krebs-Ringer PBS and incubated for $30 \mathrm{~min}$ at $37^{\circ} \mathrm{C}$. The opsonized microspheres were added to the PMNL and incubated for 30 min: 2 tubes were incubated at 
$37^{\circ} \mathrm{C}$ and the other 1 at $4^{\circ} \mathrm{C}$ (control). The reaction was stopped by adding $1.8 \mathrm{~mL}$ of cold PBS. The PMNL were washed 3 times with $1.5 \mathrm{~mL}$ of cold PBS and centrifuged at $1,700 \times g$ for $5 \mathrm{~min}$. After the final centrifugation, the PMNL were resuspended in $500 \mu \mathrm{L}$ of cold PBS and fluorescence was analyzed by flow cytometry (Ex:Em wavelengths: 535:570 nm) on a Coulter Epics XL-MCL flow cytometer (Beckman Coulter Inc.). Experiments were repeated twice.

\section{Chemotaxis Assay}

Zymosan-Activated Bovine Serum (ZAS) was prepared as described by Lamote et al. (2004). Prior to use, the ZAS was diluted 1:5 with HBSS and filtered through a $0.22-\mu \mathrm{m}$ filter.

Before the chemotaxis assay was performed, the PMNL concentration was adjusted to $5 \times 10^{6} \mathrm{cell} / \mathrm{mL}$ in RPMI medium, $1 \times$ antibiotic-antimycotic, and $5 \%$ of the serum to be tested, and incubated for $2 \mathrm{~h}$ at $37^{\circ} \mathrm{C}$ in a water-saturated $5 \% \mathrm{CO}_{2}$ atmosphere with gentle agitation $(100 \mathrm{rpm})$. The PMNL counts were verified at the beginning and end of the incubation.

A micropore Transwell Permeable Support was used to assess the chemotaxis of PMNL cells (12-mm diameter, $3 \mu \mathrm{m}$-pore size; Corning Costar, Oneonta, NY). To perform the assay, cells were adjusted to $1 \times 10^{7}$ $\mathrm{PMNL} / \mathrm{mL}$ in PBS after incubation. Two hundred microliters of PMNL suspension was added to the upper chambers and $400 \mu \mathrm{L}$ of ZAS to the lower chambers. For the negative control, $400 \mu \mathrm{L}$ of HBSS was used in the lower chamber. After incubation for $90 \mathrm{~min}$ at $37^{\circ} \mathrm{C}$ in a water-saturated $5 \% \quad \mathrm{CO}_{2}$ atmosphere, migrated PMNL were counted with a Bright-Line Hemacytometer. Results were expressed as the percentage of cells that migrated through the membrane. Each assay was performed in duplicate and the whole experiment was repeated twice.

\section{Oxidative Burst Activity Assay}

This assay was performed right after PMNL isolation (no incubation, as it greatly diminished oxidative burst capacity of the PMNL). Reactive oxygen species production by PMNL was quantified after stimulation of the cells with phorbol myristate acetate (PMA). Cell preparation $\left(100 \mu \mathrm{L}\right.$ of $10^{7}$ cells $\left./ \mathrm{mL}\right), 60 \mu \mathrm{L}$ of $1 \mathrm{mM}$ luminol [5-amino-2,3-dihydro-1,4-phthalazinedione, stock solution in dimethyl sulfoxide (DMSO); Sigma-Aldrich Corp.], and $20 \mu \mathrm{L}$ of $0.2 \mu \mathrm{g} / \mathrm{mL}$ PMA (stock solution in DMSO; Merck KGaA, Darmstadt, Germany) were added to $220 \mu \mathrm{L}$ of preheated $\left(37^{\circ} \mathrm{C}\right)$ RPMI medium without phenol red containing the serum to be tested (1\%). The measurement of $\mathrm{H}_{2} \mathrm{O}_{2}$ release was monitored using a Modulus Single Tube Luminometer (Turner Biosystems, Sunnyvale, CA) in duplicate over a period of $20 \mathrm{~min}$ at room temperature with acquisition every $10 \mathrm{~s}$. A negative control was prepared by replacing the PMA solution with an equivalent volume of DMSO. The area under the curve (AUC) was calculated over a period of 20 min with SAS software (SAS Institute, 2002). The entire experiment was repeated twice for each serum.

\section{Statistical Analysis}

Data were analyzed using the MIXED procedure of SAS Institute (2002). Effect of treatment and DIM of the cows from which the tested serum samples were collected were analyzed with the REPEATED statement. Time was used as the repeated effect and cow (treatment) as the subject. The relationship between observed immune measures and the concentration of metabolites and hormones was evaluated using the CORR procedure of SAS. The effect of supplementing cell culture media with metabolites was evaluated using Scheffe's adjustment. To avoid confounding effects due to the carrier, the effect of the metabolite dose was compared with the corresponding dose of its respective negative control (ethanol for NEFA and $\mathrm{NaCl}$ for BHBA). Differences were considered statistically significant when $P<0.05$.

\section{RESULTS}

\section{Metabolites and Hormone Concentrations in the Sera Used}

Table 1 shows the concentrations of metabolites and hormones in the different sera used in this study. Dosages were done previously (Loiselle et al., 2009). Higher concentrations of NEFA and BHBA were observed in the early lactation sera (d 2 and 5 ) in comparison to the serum at $\mathrm{d} 61$ for both groups $(1 \times$ and $2 \times)$. Lower concentrations of NEFA and BHBA were observed in the serum at $\mathrm{d} 5$ for the $1 \times$ cows in comparison to the serum at $\mathrm{d} 5$ for the $2 \times$ cows $(P<0.05)$.

\section{PBMC}

Effect of Postcalving Serum on PBMC Proliferation. Peripheral blood mononuclear cells were incubated with serum obtained on d 2, 5, and 61 postcalving from $1 \times$ or $2 \times$ cows during the first week of lactation. In nonstimulated cells, proliferation increased slightly with number of DIM when the serum was collected $(P<0.01)$, but was not affected by milking frequency (data not shown). In ConA-stimulated cells, prolifera- 


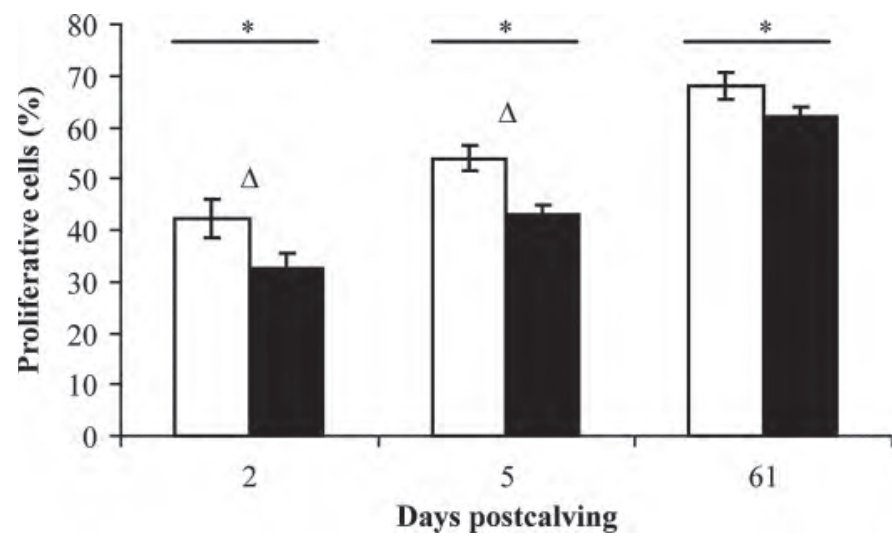

Figure 1. Percentage of proliferative cells according to the serum used for the culture of concanavalin A-stimulated peripheral blood mononuclear cells (PBMC). The PBMC were incubated with $5 \%$ of serum sampled 2, 5, and $61 \mathrm{~d}$ after calving from cows milked once (open bars) or twice (solid bars) daily during the first week of lactation. Data are presented as least squares means \pm standard error of least squares means. Statistical differences between the different days are marked with an asterisk $(* ; P<0.001)$. For each day postcalving tested, significant differences between the 2 milking frequencies are marked with a triangle $(\Delta, P<0.001)$.

tion increased with the number of DIM (Figure 1; $P$ $<0.001)$. Proliferation was higher for serum harvested from $1 \times$ cows than from $2 \times$ cows $(P<0.001)$.

The relationship between metabolite and hormone concentrations (Table 1) and PBMC proliferation was evaluated. The relationship was a negative correlation with NEFA ( $\mathrm{r}=-0.86, P<0.001)$. A negative correlation with serum BHBA $(\mathrm{r}=-0.54, P<0.01)$ was found. Proliferation was not correlated with calcium, urea, bilirubin, phosphorus, 17 $\beta$-estradiol, or stanniocalcin-1. The concentrations of BHBA and NEFA were correlated $(\mathrm{r}=0.64, P<0.0001)$.

Effect of NEFA and BHBA on Proliferation. To evaluate whether a cause-and-effect relationship existed between NEFA and BHBA concentration and PBMC proliferation, d-61 sera were supplemented with enough NEFA or BHBA, or both (or their respective negative controls), to obtain the same concentration as in the corresponding $\mathrm{d}-5$ serum. In this assay, $\mathrm{d}-5$ serum had a negative effect on proliferation compared with d-61 serum $(P<0.001$; Figure 2$)$. No difference was observed when proliferation assays were performed with ethanol or $\mathrm{NaCl}$, or both $(P>0.15$; data not shown). No effect of BHBA was observed either, because proliferation was equivalent for d-61 sera and d-61 serum supplemented with BHBA $(P>0.15)$. Addition of NEFA to d-61 serum decreased proliferation $(P<$ 0.001). The addition of both BHBA and NEFA to the culture medium resulted in a decrease in proliferation equivalent to that obtained with NEFA alone.

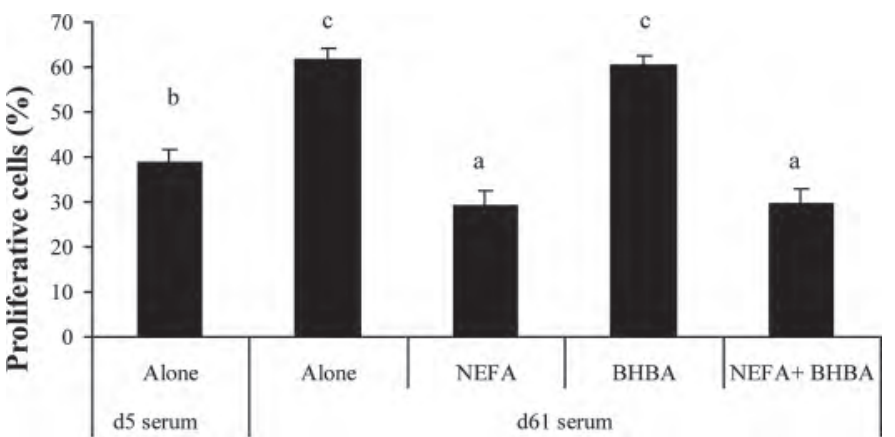

Tested conditions

Figure 2. Effect of sera sampled on d 5 or 61 postcalving or d-61 serum supplemented with NEFA or BHBA, or both, on the proliferation capacity of concanavalin A-stimulated peripheral blood mononuclear cells (PBMC) from healthy cows. Data are presented as least squares means \pm standard error of least squares means. Data represent the difference between proliferation obtained with concanavalin A and proliferation obtained without stimulation. The different letters indicate significant differences $(P<0.01)$.

To further investigate the effect of NEFA and BHBA on PBMC proliferation, dose-effect experiments were performed by adding increasing concentrations of these metabolites to the proliferation medium. As shown in Figure 3 (panel A), supplementation with NEFA led to a drastic decrease in proliferation $(P<0.001)$. No difference in proliferation was observed between the positive control (proliferation medium without NEFA) and negative controls (increasing volume of ethanol; $P$ $>0.15)$, except for the highest dose $(P<0.05$; data not shown). Proliferation was not affected by BHBA addition, except for the highest dose (1 $\mathrm{m} M$; Figure 3, panel B). No difference in proliferation was observed between the positive (proliferation medium) and negative controls (increasing $\mathrm{NaCl}$ concentrations; $P>0.15$; data not shown).

\section{PBMC Production of IFN-Y}

To evaluate the effect of serum composition on IFN- $\gamma$ production, PBMC were incubated for $24 \mathrm{~h}$ with $5 \%$ d-5 or -61 sera. The IFN- $\gamma$ production decreased $(P<$ $0.0001)$ when PBMC were incubated with d-5 serum (Figure 4). The IFN- $\gamma$ production was not affected by milking frequency (data not shown). To test the role of NEFA and BHBA, d-61 serum was supplemented with those 2 compounds or with their respective negative controls (ethanol and $\mathrm{NaCl}$ ) to reach the level present in $\mathrm{d}-5$ serum. The IFN- $\gamma$ production was lower after incubation of the PBMC with d-61 serum supplemented with NEFA $(P<0.01)$ and with d-61 serum alone, and lower than IFN- $\gamma$ production after incubation with d-61 serum supplemented with ethanol $(P<0.01)$. There- 
A)

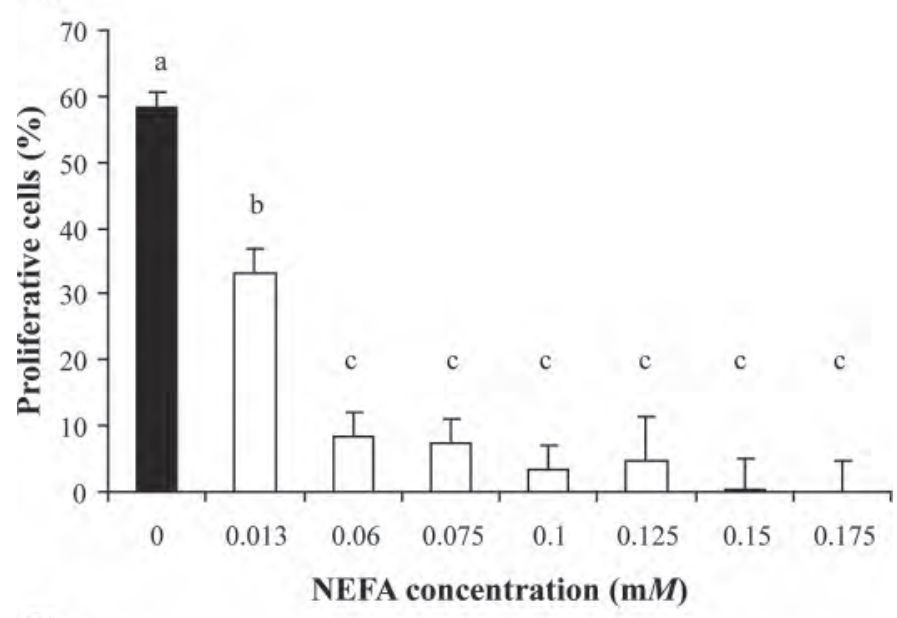

B)

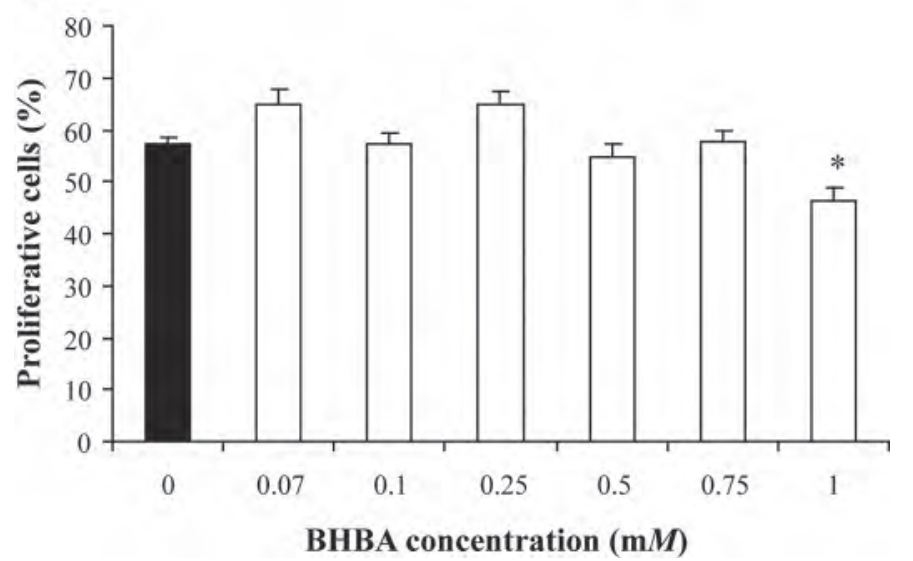

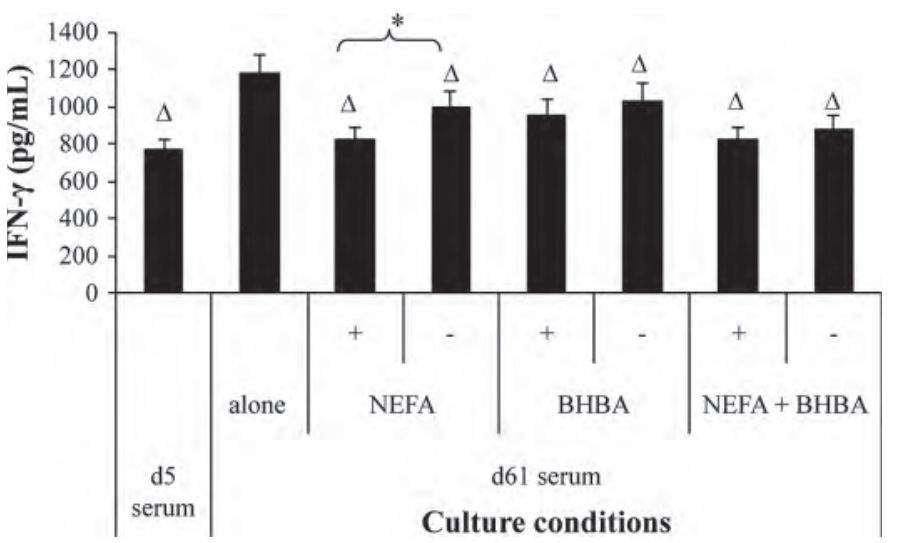

Figure 4. Concentration of IFN- $\gamma$ in the supernatant of concanavalin A-stimulated peripheral blood mononuclear cells (PBMC) incubated with $5 \%$ serum sampled on d 5 or 61 postcalving or d-61 serum supplemented with NEFA or BHBA, or both, or their respective negative controls to reach d-5 serum concentration. Data are means \pm standard errors of the means; $\Delta$ represents significantly different values $(P<0.01)$ in relation to d-61 serum; * represents significant difference between a metabolite and its negative control $(P<0.01)$.

PMNL

Effect of Postcalving Serum on PMNL Chemotaxis. Chemotaxis was assayed for after $2 \mathrm{~h}$ incubation of PMNL with $\mathrm{d}-2,-5$, and -61 serum from $1 \times$ or $2 \times$ cows during the first week of lactation. No effect was found of DIM or milking frequency on the proportion of cells that migrated $(P>0.15$; data not shown).

Figure 3. Dose effect of concentrations of NEFA (A) and BHBA (B) on concanavalin A-stimulated peripheral blood mononuclear cell (PBMC) proliferation. Data are presented as least squares means \pm standard error of least squares means. Letters are different for significant differences $(P<0.001)$ in panel $\mathrm{A}$. In panel $\mathrm{B}, *$ indicates values different from the control $(0 \mathrm{~m} M ; P<0.05)$.

fore, NEFA seems to have a negative effect on IFN- $\gamma$ production. Adding BHBA to d-61 serum decreased IFN- $\gamma$ production $(P<0.01)$. The IFN- $\gamma$ production by BHBA-supplemented serum was similar to that of PBMC incubated with d-61 serum supplemented with an equivalent $\mathrm{Na}$ concentration $(P<0.5)$.

The dose effect of NEFA and BHBA was evaluated. Production of IFN- $\gamma$ decreased linearly as the NEFA concentration increased in the medium $(P<0.01$; Figure 5). The IFN- $\gamma$ production decreased as the concentration of ethanol increased $(P<0.01)$; however, inhibition was greater for NEFA than for ethanol $(P$ $<0.01)$. The IFN- $\gamma$ production was not affected by BHBA $(P>0.1$; data not shown).

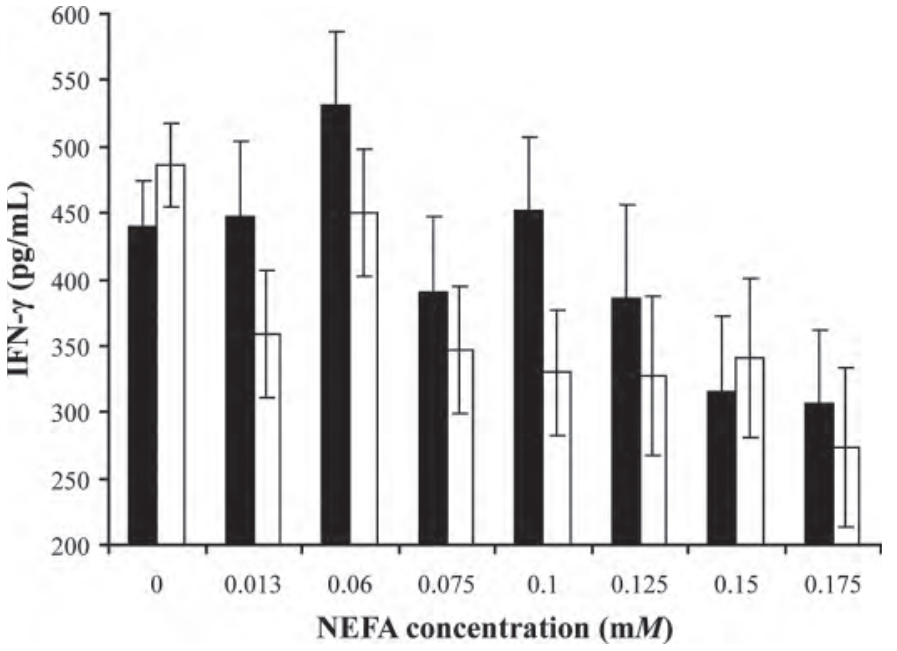

Figure 5. Dose effect of concentrations of NEFA on peripheral blood mononuclear cell (PBMC) secretion of IFN- $\gamma$. Open bars represent NEFA and closed bars represent the negative control (ethanol). Data are least squares means \pm standard error of least squares means. Secretion of IFN- $\gamma$ decreased as the NEFA or ethanol concentration increased in the medium $(P<0.01)$. 


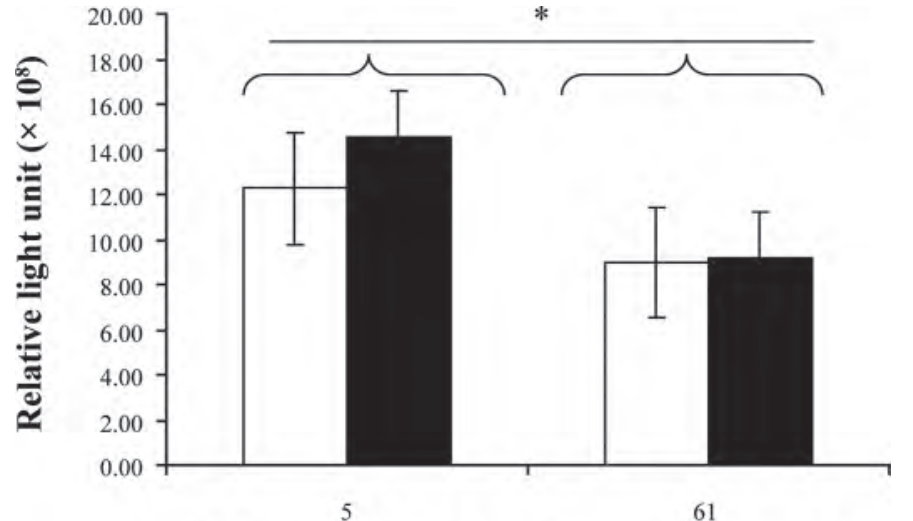

Days postcalving when serum was sampled

Figure 6. Oxidative burst of PMNL incubated with $1 \%$ of serum sampled on d 5 and 61 postcalving from cows milked once (open bars) or twice (solid bars) daily during the first week of lactation. Data are presented as least squares means \pm standard error of least squares means. ${ }^{*}$ represents significantly different values $(P<0.05)$.

Effect of Postcalving Serum on PMNL Phagocytosis. Phagocytosis was evaluated after $2 \mathrm{~h}$ of incubation of PMNL with serum samples (Table 2). Phagocytic activity was evaluated as the percentage of phagocytic neutrophils, phagocytosis intensity corresponds to the quantity of ingested fluorospheres, and the phagocytic index is the combination of the 2 variables. No effect of milking frequency was observed $(P>0.15)$ for the 3 measures. More PMNL were able to phagocytize fluorospheres after incubation with d-2 serum $(P<0.01)$ than with $\mathrm{d}-5$ or -61 sera. Moreover, the number of PMNL able to phagocytize fluorospheres tended to be greater after incubation with d-5 serum than with $\mathrm{d}-61$ serum $(P=0.06)$. The same pattern was observed for the percentage of ingested fluorescent beads. When phagocytosis was evaluated as a combination of the percentage of phagocytic PMNL and the quantity ingested, the same conclusions were observed. Differences were observed $(P<0.02)$ between the serum samples (d 2, 5, or 61). Serum samples on d 2 and 5 led to more phagocytosis than did d-61 serum.
Effect of Postcalving Serum on PMNL Oxidative Burst. Oxidative burst was analyzed right after PMNL isolation because incubation impaired this function (data not shown). The percentage of serum was decreased to $1 \%$ (instead of $5 \%$ for the rest of the study) for the same reason (data not shown). Oxidative burst was performed with $\mathrm{d}-5$ and -61 sera from $1 \times$ or $2 \times$ cows during the first week of lactation (Figure $6)$. No effect of milking frequency was observed $(P>$ 0.15 ), but PMNL produced a larger amount of reactive oxygen species when they were in a medium containing d-5 serum $(P<0.05)$. Dose effects of NEFA or BHBA are shown in Figure 7. High NEFA concentrations decreased the oxidative burst activity of the PMNL $(P<$ $0.01)$. The BHBA concentration did not affect oxidative burst $(P>0.15)$.

\section{DISCUSSION}

A slower transition between dry-off and lactation achieved by milking 1 time during the first week of lactation led to a decrease in metabolic disturbances, as indicated by the better glycemia and the lower NEFA and BHBA concentrations (Loiselle et al., 2009). Peripheral blood mononuclear cells functions were not markedly depressed in the peripartum period, nor were they affected when PBMC were cultivated in vitro in a conventional medium. The PBMC from midlactation cows incubated with early lactation serum (d 2 and 5) showed a negative effect on PBMC proliferation capacity and IFN- $\gamma$ production. Moreover, PBMC proliferation was greater for the serum samples from $1 \times$ cows than for the serum samples from $2 \times$ cows. This suggests that impaired PBMC functions are attributable more to serum composition at the beginning of lactation than to an autonomous cell defect.

A negative correlation was observed between serum NEFA concentration and proliferation of PBMC ( $\mathrm{r}=$ -0.86 ). The involvement of NEFA in peripartum immunosuppression is supported by the supplementation of d-61 serum with a d-5 equivalent concentration

Table 2. Least squares means ( $\pm \mathrm{SE}$ of LSM) of phagocytosis activity of PMNL after $2 \mathrm{~h}$ of incubation with $5 \%$ serum sample on $\mathrm{d} 2,5$, and 61 postcalving

\begin{tabular}{lccc}
\hline & \multicolumn{3}{c}{ Day postcalving when serum was sampled } \\
\cline { 2 - 4 } Phagocytosis parameter & 2 & 5 & 61 \\
\hline \% of phagocytic neutrophils & $74.57^{\mathrm{a}} \pm 1.98$ & $71.72^{\mathrm{b}} \pm 1.93$ & $68.94^{\mathrm{b}} \pm 1.93$ \\
Phagocytosis intensity & $64.53^{\mathrm{a}} \pm 2.53$ & $61.06^{\mathrm{b}} \pm 2.45$ & $57.13^{\mathrm{b}} \pm 2.45$ \\
Index of phagocytosis & $4,838.7^{\mathrm{a}} \pm 216.94$ & $4,474.14^{\mathrm{b}} \pm 207.7$ & $3,952.1^{\mathrm{c}} \pm 207.43$ \\
\hline${ }^{\mathrm{a}-\mathrm{c}}$ Each different letter within a row represents statistically different values $(P<0.001)$. \\
${ }^{1}$ Phagocytosis activity was evaluated on the basis of 2 measures: the percentage of phagocytic PMNL and \\
phagocytosis intensity (i.e., the quantity of ingested fluorospheres). The index of phagocytosis is a combination \\
of the 2 measures.
\end{tabular}


A)

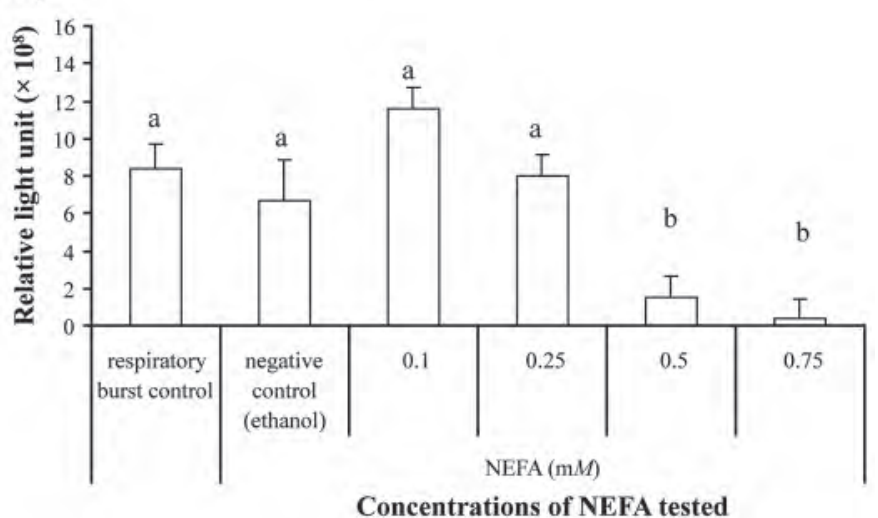

B)

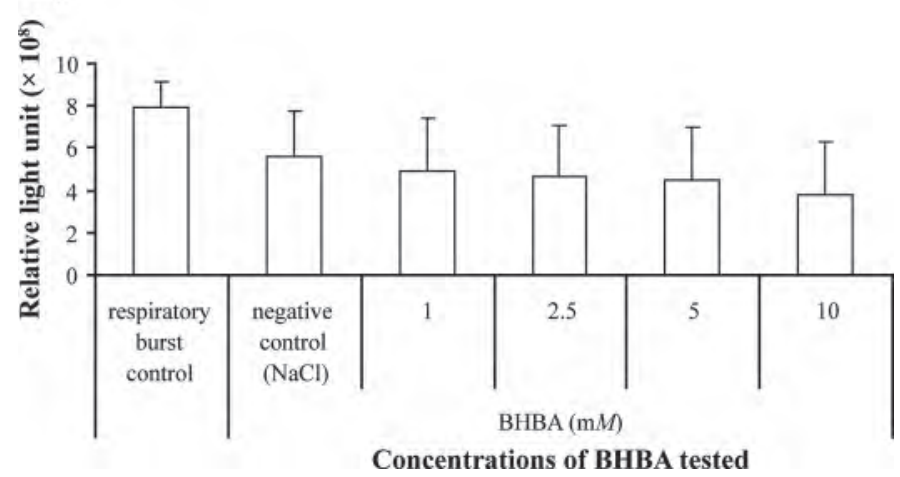

Figure 7. Dose effect of increasing concentrations of NEFA (A) and BHBA (B) on PMNL oxidative burst. For each metabolite, the negative control equivalent to the highest concentration is presented [i.e., an equal volume of ethanol for NEFA or an equal concentration of $\mathrm{Na}$ (from $\mathrm{NaCl}$ ) for $\mathrm{BHBA}$. Data are least squares means \pm standard error of least squares means. Letters are different for significant differences $(P<0.01 ; \mathrm{A})$. No statistical differences were observed for the BHBA dose effect $(\mathrm{B})$.

of NEFA, which resulted in proliferation and IFN- $\gamma$ production near that observed with d-5 serum. Furthermore, a dose-effect relationship was established for both measures and the NEFA concentration. Lacetera et al. (2002) showed that NEFA concentrations greater than $250 \mu M$ inhibited ConA-induced proliferation of ovine PBMC. Similarly, bovine PBMC proliferation and INF- $\gamma$ production were inhibited by NEFA concentrations greater than 500 and $125 \mu M$, respectively (Lacetera et al., 2004). In the current study, a NEFA concentration as low as $13 \mu M$ was able to inhibit PBMC proliferation and INF- $\gamma$ production. To reach an equivalent concentration of NEFA in a test medium, a serum sample would have to contain at least 260 $\mu M$ NEFA, as this media included $5 \%$ serum, which is lower than the concentration of the early lactation serum used.
A negative correlation was observed between serum BHBA concentration and proliferation of PBMC ( $\mathrm{r}$ $=-0.54)$. The BHBA only had a negative effect on PBMC proliferation at a concentration of $1 \mathrm{~m} M$. To reach an equivalent concentration of BHBA in the test medium, a serum sample would have to contain at least $20 \mathrm{~m} M$ BHBA, which is much higher than that of any of the serum samples we used. No direct effect of BHBA was observed on the proliferation and IFN- $\gamma$ production of PBMC. Accordingly, when tested alone, BHBA did not affect proliferation or IgM secretion of ewe PBMC (Lacetera et al., 2002). In cattle, BHBA and acetoacetate had minimal effects on PBMC proliferation (Franklin et al., 1991) or IgM secretion (Nonnecke et al., 1992). Therefore, the negative correlation between PBMC proliferation and BHBA in serum was more likely related to the close association between BHBA and NEFA concentrations than to a direct effect of BHBA on PBMC function.

Phagocytosis and oxidative burst were greater for PMNL incubated with early lactation serum samples. Nevertheless, NEFA were able to inhibit oxidative burst at concentrations above $500 \mu M$. Such a concentration is too high to be reached by any of the serum samples diluted at the $1 \%$ level. On the other hand, a proinflammatory environment is present during the periparturient period (Koets et al., 1998). Indeed, abundant production of proinflammatory cytokines occurs in the reproductive tract during this period (van Engelen et al., 2009). The presence of proinflammatory mediators into d-5 serum may have been sufficient to stimulate PMNL functions despite the high concentration of NEFA.

Dose-response assays have shown that NEFA have a negative effect on oxidative burst. Scalia et al. (2006) observed no effects for moderate concentrations of NEFA, but reported an increase in phagocytosisinduced oxidative burst at high concentrations $(>1$ $\mathrm{m} M)$. The high NEFA concentrations were associated with decreased viability and increased necrosis. The differences between the 2 studies may be due to the methodology used (PMA-induced oxidative burst versus phagocytosis-induced oxidative burst). Our results suggest that PMNL are less sensitive to NEFA than are PBMC, but they may nevertheless be affected by the very high level reached in the early postpartum period. Accordingly, Hammon et al. (2006) reported a negative relationship between PMNL myeloperoxidase activity and NEFA concentration encountered at the beginning of lactation.

No decrease in the oxidative burst activity of the PMNL was observed for BHBA concentrations ranging from 1 to $10 \mathrm{mM}$. It has been reported (Hoeben et al., 1997) that subketotic concentrations (1 to $2.5 \mathrm{mM}$ ) of 
BHBA inhibit the oxidative burst of PMNL (after 30 min incubation). The difference may be because in our study no incubation was performed before the assay, as we observed that PMNL incubated for $2 \mathrm{~h}$ died shortly after stimulation by PMA. A slight reduction in superoxide release by $2.4 \mathrm{~m} M$ BHBA but not by $4.8 \mathrm{~m} M$ was reported in ovine neutrophils (Sartorelli et al., 2000).

Kehrli et al. (1989) reported that PMNL functions are depressed in the peripartum period. The increased PMNL demand during this period results in the rapid mobilization of bone marrow PMNL and an increase in the proportion of immature PMNL in circulation. Accordingly, PMNL collected after an intramammary challenge show an increase in the proportion of immature cells and a decreased ability to phagocytize bacteria (Moyes et al., 2009a). The effect of cell maturity could not be tested in our model as PMNL were isolated from mid- to late-lactation cows.

The peripartum period is characterized by a negative energy balance associated with transient immunosuppression and a higher incidence of diseases in dairy cows. Results of this study indicate that the increase in circulating NEFA impairs PBMC functions. The PMNL oxidative burst seemed less sensitive to NEFA, but may be affected by very high levels. Therefore, management approaches that decrease the negative energy balance and the increase in NEFA at the beginning of lactation, such as shortening the dry-off period (Grummer et al., 2010), improving the diet during the transition period (Beever, 2006), or limiting milk production in the first days of lactation will likely improve resistance to infection. In addition, the NEFA concentration in the blood of dairy cows may be considered as an indicator of the immune and metabolic status of the cows at the beginning of lactation.

\section{ACKNOWLEDGMENTS}

This research was financially supported by the Dairy Farmers of Canada (Ottawa, ON, Canada), Agriculture and Agri-Food Canada (Ottawa, ON, Canada), and the Natural Science and Engineering Research Council of Canada (Ottawa, ON, Canada). The authors thank Lisette St-James, Andréa Fréchette, Simon Charette, François Marcouiller, Martin Romarie, and Etienne Brizard, as well as the dairy barn staff at the Dairy and Swine Research and Development Centre (Sherbrooke, QC, Canada), for their invaluable help.

\section{REFERENCES}

Accorsi, P. A., N. Govoni, R. Gaiani, C. Pezzi, E. Seren, and C. Tamanini. 2005. Leptin, GH, PRL, insulin and metabolic parameters throughout the dry period and lactation in dairy cows. Reprod. Domest. Anim. 40:217-223.
Beever, D. E. 2006. The impact of controlled nutrition during the dry period on dairy cow health, fertility and performance. Anim. Reprod. Sci. 96:212-226.

Busato, A., D. Faissle, U. Küpfer, and J. W. Blum. 2002. Body condition scores in dairy cows: Associations with metabolic and endocrine changes in healthy dairy cows. J. Vet. Med. A Physiol. Pathol. Clin. Med. 49:455-460.

Drackley, J. K. 1999. Biology of dairy cows during the transition period: The final frontier? J. Dairy Sci. 82:2259-2273.

Franklin, S. T., J. W. Young, and B. J. Nonnecke. 1991. Effects of ketones, acetate, butyrate, and glucose on bovine lymphocyte proliferation. J. Dairy Sci. 74:2507-2514.

Goff, J. P., and R. L. Horst. 1997. Physiological changes at parturition and their relationship to metabolic disorders. J. Dairy Sci. 80:1260-1268.

Goff, J. P., K. Kimura, and R. L. Horst. 2002. Effect of mastectomy on milk fever, energy, and vitamins $\mathrm{A}, \mathrm{E}$, and $\beta$-carotene status at parturition. J. Dairy Sci. 85:1427-1436.

Grummer, R. R., M. C. Wiltbank, P. M. Fricke, R. D. Watters, and N. Silva-Del-Rio. 2010. Management of dry and transition cows to improve energy balance and reproduction. J. Reprod. Dev. 56(Suppl.):S22-S28.

Hammon, D. S., I. M. Evjen, T. R. Dhiman, J. P. Goff, and J. L. Walters. 2006. Neutrophil function and energy status in Holstein cows with uterine health disorders. Vet. Immunol. Immunopathol. 113:21-29.

Hoeben, D., R. Heyneman, and C. Burvenich. 1997. Elevated levels of beta-hydroxybutyric acid in periparturient cows and in vitro effect on respiratory burst activity of bovine neutrophils. Vet. Immunol. Immunopathol. 58:165-170.

Hoeben, D., E. Monfardini, G. Opsomer, C. Burvenich, H. Dosogne, A. De Kruif, and J.-F. Beckers. 2000. Chemiluminescence of bovine polymorphonuclear leucocytes during the periparturient period and relation with metabolic markers and bovine pregnancy-associated glycoprotein. J. Dairy Res. 67:249-259.

Kehrli, M. E., Jr., and J. A. Harp. 2001. Immunity in the mammary gland. Vet. Clin. North Am. Food Anim. Pract. 17:495-516. (vi.).

Kehrli, M. E. Jr., B. J. Nonnecke, and J. A. Roth. 1989. Alterations in bovine neutrophil function during the periparturient period. Am. J. Vet. Res. 50:207-214.

Koets, A. P., N. de Schwartz, P. Tooten, M. Kankofer, J. M. Broekhuijsen-Davies, V. P. M. G. Rutten, L. A. M. G. van Leengoed, M. A. M. Taverne, and E. Gruys. 1998. Release of proinflammatory cytokines related to luteolysis and the periparturient acute phase response in prostaglandin-induced parturition in cows. Theriogenology 49:797-812.

Lacetera, N., O. Franci, D. Scalia, U. Bernabucci, B. Ronchi, and A. Nardone. 2002. Effects of nonesterified fatty acids and betahydroxybutyrate on functions of mononuclear cells obtained from ewes. Am. J. Vet. Res. 63:414-418.

Lacetera, N., D. Scalia, U. Bernabucci, B. Ronchi, D. Pirazzi, and A. Nardone. 2005. Lymphocyte functions in overconditioned cows around parturition. J. Dairy Sci. 88:2010-2016.

Lacetera, N., D. Scalia, O. Franci, U. Bernabucci, B. Ronchi, and A. Nardone. 2004. Short communication: Effects of nonesterified fatty acids on lymphocyte function in dairy heifers. J. Dairy Sci. 87:1012-1014.

Lamote, I., E. Meyer, L. Duchateau, and C. Burvenich. 2004. Influence of $17 \beta$-estradiol, progesterone, and dexamethasone on diapedesis and viability of bovine blood polymorphonuclear leukocytes. J. Dairy Sci. 87:3340-3349.

Loiselle, M. C., C. Ster, B. G. Talbot, X. Zhao, G. F. Wagner, Y. R. Boisclair, and P. Lacasse. 2009. Impact of postpartum milking frequency on the immune system and the blood metabolite concentration of dairy cows. J. Dairy Sci. 92:1900-1912.

Mallard, B. A., J. C. Dekkers, M. J. Ireland, K. E. Leslie, S. Sharif, C L. Vankampen, L. Wagter, and B. N. Wilkie. 1998. Alteration in immune responsiveness during the peripartum period and its ramification on dairy cow and calf health. J. Dairy Sci. 81:585-595.

Moreira da Silva, F., C. Burvenich, A. M. Massart Leën, and L. Brossé. 1998. Assessment of blood neutrophil oxidative burst activ- 
ity in dairy cows during the period of parturition. Anim. Sci. $67: 421-426$.

Moyes, K. M., J. K. Drackley, J. L. Salak-Johnson, D. E. Morin, J. C. Hope, and J. J. Loor. 2009a. Dietary-induced negative energy balance has minimal effects on innate immunity during a Streptococcus uberis mastitis challenge in dairy cows during midlactation. J. Dairy Sci. 92:4301-4316.

Moyes, K. M., T. Larsen, N. C. Friggens, J. K. Drackley, and K. L. Ingvartsen. 2009b. Identification of potential markers in blood for the development of subclinical and clinical mastitis in dairy cattle at parturition and during early lactation. J. Dairy Sci. 92:5419-5428.

Nonnecke, B. J., S. T. Franklin, and J. W. Young. 1992. Effects of ketones, acetate, and glucose on in vitro immunoglobulin secretion by bovine lymphocytes. J. Dairy Sci. 75:982-990.

Nonnecke, B. J., K. Kimura, J. P. Goff, and M. E. Kehrli Jr. 2003. Effects of the mammary gland on functional capacities of blood mononuclear leukocyte populations from periparturient cows. J. Dairy Sci. 86:2359-2368

Ospina, P. A., D. V. Nydam, T. Stokol, and T. R. Overton. 2010 Evaluation of nonesterified fatty acids and $\beta$-hydroxybutyrate in transition dairy cattle in the northeastern United States: Critical thresholds for prediction of clinical diseases. J. Dairy Sci. 93:546-554.

Sartorelli, P., S. Paltrinieri, and S. Comazzi. 2000. Non-specific immunity and ketone bodies. II: In vitro studies on adherence and superoxide anion production in ovine neutrophils. J. Vet. Med. Ser A $47: 1-8$

SAS Institute. 2002. Statistical Analysis System: Release 9.1. SAS Institute Inc., Cary, NC.

Scalia, D., N. Lacetera, U. Bernabucci, K. Demeyere, L. Duchateau, and C. Burvenich. 2006. In vitro effects of nonesterified fatty acids on bovine neutrophils oxidative burst and viability. J. Dairy Sci. $89: 147-154$.

Suriyasathaporn, W., C. Heuer, E. N. Noordhuizen-Stassen, and Y. H. Schukken. 2000. Hyperketonemia and the impairment of udder defense: A review. Vet. Res. 31:397-412.

van Engelen, E., M. W. De Groot, V. N. A. Breeveld-Dwarkasing, M. E. Everts, G. C. van der Weyden, M. A. M. Taverne, and V. P. M. G. Rutten. 2009. Cervical ripening and parturition in cows are driven by a cascade of pro inflammatory cytokines. Reprod. Domest. Anim. 44:834-841. 